is as fundamental to daily life as a fair trial is to criminal procedure, and for the guarantee of a right to a high standard of healthcare to be realized, it must imply a right to translation).

Dążenie do pogodzenia interesu państwa w zminimalizowaniu liczby języków urzędowych i zapewnieniu sprawnej komunikacji w społeczeństwie obywatelskim z powyższymi postulatami prowadzi do wniosku, że dwie główne reformy polityki integracji obywatelskiej, które należałoby zdaniem Autorki wprowadzić, to zapewnienie bezpłatnych kursów językowych dla migrantów oraz zagwarantowanie dostępu do tłumaczeń w placówkach opieki zdrowotnej. Bezpłatne kursy językowe (w języku większości) dałyby imigrantom z mniejszości językowych umiejętności niezbędne do poruszania się w nowym kraju bez nadmiernego obciążania ich kosztami. Gwarantowane tłumaczenie w opiece zdrowotnej poprawiłoby wyniki zdrowotne migrantów, wspierając ich wejście na rynek pracy i pozostanie na nim oraz rozwój więzi ekonomicznych i społecznych z nowymi społecznościami. Autorka wskazuje na pewne ograniczenia związane z ewentualną obecnością licznych grup etnicznych posługujących się rozmaitymi językami oraz podkreśla konieczność odpowiedniego komunikowania tych postulatów społeczeństwu żywiącemu wskazywane wcześniej obawy. Rozważania kończy jednak konstatacją, że inwestując w udaną integrację imigrantów, kraj przyjmujący może promować zarówno prawa człowieka, jak i spójność społeczną przy jednoczesnej poprawie wyników gospodarczych.

DOI: $10.14746 /$ spp.2021.4.36.8

\title{
Matthiew Ormsbee, The Fifth Instrument of National Power: How Mass Migrations Impact National Security (Piąty instrument potęgi narodowej: jak masowe migracje wpływają na bezpieczeństwo narodowe), "Creighton Law Review" 2021, vol. 54, no. 3, s. 381-410
}

Problematyka, będąca przedmiotem prezentowanego artykułu, mieści się zasadniczo w zakresie nauki o stosunkach międzynarodowych, równocześnie jednak, z uwagi na to, że obejmuje kwestie bezpieczeństwa państwa, ma istotne znaczenie dla prawa migracyjnego i jego kształtowania na poziomie globalnym, regionalnym i krajowym. Bezpieczeństwo państwa w wymiarze zewnętrznym oraz bezpieczeństwo i porządek publiczny w wymiarze wewnętrznym należą do podstawowych dóbr chronionych w systemach prawa migracyjnego różnych państw. Poruszone przez Autora aspekty mają szczególne znaczenie w dobie trwającego na granicy polsko-białoruskiej kryzysu humanitarnego związanego z wykorzystaniem przez jedną stronę ruchów migracyjnych jako swoistej broni i ze sposobem (także w wymiarze legislacyjnym) reagowania na ten fakt przez drugą stronę.

W artykule w pierwszej kolejności opisano, czym są masowe ruchy migracyjne (mass movements of people) oraz zaprezentowano ich kontekst polityczny i prawnomiędzynarodowy. Punktem wyjścia jest definicja ONZ określająca migranta jako osobę, która przemieszcza się, przekraczając granicę międzynarodową, lub przemieszcza się w obrębie państwa, jednak na znaczną odległość od miejsca zwykłego pobytu. Autor podaje dane, z których wynika, że chodzi o grupę stanowiącą ok. 3,5\% światowej 
populacji. Masowe ruchy migracyjne są z natury zjawiskami o dużej skali, mającymi potencjał wpływania na stan populacji, gospodarki, obronność i stabilność polityczną danego państwa. Autor przytacza najważniejsze czynniki środowiskowe, społeczne, polityczne i gospodarcze, leżące u podstaw ruchów migracyjnych, oraz wskazuje na wpływ, jaki wywierają one na różne aspekty funkcjonowania państwa, w szczególności na jego bezpieczeństwo. W tym zakresie Autor zwięźle omawia następujące problemy: możliwa obecność niebezpiecznych jednostek lub grup (np. terrorystycznych), które z łatwością mogą ukryć się w masie migrantów; potencjalne naruszenie politycznej równowagi w skali międzynarodowej (takie jak np. napięcia w Unii Europejskiej na tle braku solidarności w obciążeniu skutkami kryzysu migracyjnego z roku 2015) i krajowej (np. rosnące w siłę partie populistyczne i nacjonalistyczne); ryzyko społecznej dekompozycji (w szczególności w braku adekwatnej polityki integracyjnej).

W dalszej części Autor wskazuje, że jeśli masowe ruchy migracyjne zostaną zaakceptowane jako pewien stały element porządku świata, to pozwoli to skoncentrować się na ich wpływie na bezpieczeństwo i lepiej zapobiegać negatywnym skutkom w tym obszarze. W szczególności proponuje, aby właściwe władze postrzegały masowe ruchy migracyjne $\mathrm{w}$ kategoriach piątego instrumentu potęgi narodowej (instrument of national power) obok tradycyjnie wyróżnianych: dyplomacji, informacji, siły militarnej i gospodarki. W ostatniej części artykułu Autor przedstawia propozycje będące konsekwencją takiego podejścia. Jako punkt wyjścia proponuje uwzględnienie na szeroką skalę niewiążącego prawnie dokumentu ONZ - przyjętego w 2018 r. Światowego Paktu w sprawie Migracji (Global Compact for Safe, Orderly and Regular Migration), jako podstawy do umów i porozumień dwu-i wielostronnych. Jako potencjalną bazę do wykorzystania przy projektowaniu nowych ram prawnych Autor wskazuje Model International Mobility Convention (Modelowa międzynarodowa konwencja o mobilności). Ten programowy dokument został opracowany w latach 2015-2017 przez komisję złożoną z wybitnych ekspertów w dziedzinie migracji, praw człowieka, bezpieczeństwa narodowego i ekonomii pracy. Rozwiązania w nim proponowane miałyby między innymi uzupełnić lub naprawić niedostatki dwóch podstawowych umów międzynarodowych odnoszących się do migracji i obowiązujących w systemie uniwersalnym, jakimi są Konwencja genewska dotycząca statusu uchodźców z 1951 r. wraz z protokołem nowojorskim z 1967 r. oraz Międzynarodowa konwencja o ochronie praw wszystkich pracowników-migrantów i członków ich rodzin z 1990 r. W dalszej kolejności Autor omawia propozycje konkretnych rozwiązań w kontekście amerykańskim, związanych ze strukturą wojskową i administracyjną USA, a także w kontekście relacji USA i ich sojuszników na arenie międzynarodowej. Ważnym elementem tych rozważań jest propozycja odnosząca się do systemu gromadzenia i udostępniania informacji dotyczących masowych ruchów migracyjnych. W ocenie Autora dzielenie się nimi byłoby korzystniejsze niż ich utajnianie: state's power does not grow by keeping information to itself; rather, defenses are stronger collectively when multiple data points corroborate strengths and reveal weaknesses.

Agnieszka Narożniak* DOI: 10.14746/spp.2021.4.36.9

* Agnieszka Narożniak, dr, Wyższa Szkoła Bankowa w Poznaniu, e-mail: agnieszka. narozniak@wsb.poznan.pl,https;//orcid.org/0000-0002-3091-9849. 